University of Nebraska - Lincoln

DigitalCommons@University of Nebraska - Lincoln

USDA National Wildlife Research Center - Staff Publications
U.S. Department of Agriculture: Animal and Plant Health Inspection Service

2011

Partitioning Of Anthropogenic Watering Sites By Desert Carnivores.

Todd C. Atwood

USDA National Wildlife Research Center, Fort Collins, CO, todd.c.atwood@aphis.usda.gov

Tricia L. Fry

USDA/APHIS/Wildlife Services' National Wildlife Research Center, tricia.I.fry@aphis.usda.gov

Bruce Leland

USDA-APHIS-Wildlife Services

Follow this and additional works at: https://digitalcommons.unl.edu/icwdm_usdanwrc

Part of the Environmental Sciences Commons, and the Life Sciences Commons

Atwood, Todd C.; Fry, Tricia L.; and Leland, Bruce, "Partitioning Of Anthropogenic Watering Sites By Desert Carnivores." (2011). USDA National Wildlife Research Center - Staff Publications. 1014.

https://digitalcommons.unl.edu/icwdm_usdanwrc/1014

This Article is brought to you for free and open access by the U.S. Department of Agriculture: Animal and Plant Health Inspection Service at DigitalCommons@University of Nebraska - Lincoln. It has been accepted for inclusion in USDA National Wildlife Research Center - Staff Publications by an authorized administrator of DigitalCommons@University of Nebraska - Lincoln. 


\title{
Partitioning of Anthropogenic Watering Sites by Desert Carnivores
}

\author{
TODD C. ATWOOD, ${ }^{\mathbf{1}}$ United States Department of Agriculture, Wildife Services, National Wildlife Research Center, Fort Collins, CO 80521, \\ USA
}

TRICIA L. FRY, United States Department of Agriculture, Wildlife Services, National Wildife Research Center, Fort Collins, CO 80521, USA

BRUCE R. LELAND, United States Department of Agriculture, Wildlife Services, San Antonio, TX 78201, USA

\begin{abstract}
We investigated the role of water features as focal attractors for gray foxes (Urocyon cinereoargenteus), coyotes (Canis latrans), and bobcats (Felis rufus) in west Texas to determine if they were foci for interspecific interaction. Mixed effects models indicated that species partitioned use of water features spatially and temporally. Linear models indicated factors influencing relative activity at water features varied by species. For coyotes and bobcats, the water availability model, containing days since last rainfall and nearest-neighbor distance to water was best supported by the data, with relative activity increasing with time between rainfall and distance between waters. For gray foxes, the best approximating model indicated that relative activity was inversely correlated to coyote and bobcat activity indices, and positively correlated to topographical complexity. Encounters between carnivore species were low, with most occurring between coyotes and gray foxes, followed by coyotes and bobcats, and bobcats and gray foxes. These findings suggest a behavioral-environmental mechanism that may function to modulate resource partitioning by carnivores in the arid West. (c) 2011 The Wildlife Society.
\end{abstract}

KEY WORDS carnivore, Chihuahuan desert, competition, interaction, resource partitioning, water.

Interspecific competition is a frequently occurring phenomenon (Connell 1983) that can play a determinative role in governing community structure where species exploit limited resources (Schoener 1983, Chase et al. 2002). Among carnivores, interspecific interactions typically are asymmetrical, with one species having a stronger competitive effect than the other (Atwood and Gese 2008). This asymmetry most often is influenced by differences in body size (Polis et al. 1989, Crooks and Van Vuren 1995, Davies et al. 2007) with larger species benefiting from a direct size effect by incurring lower costs from interspecific interactions than smaller species. For subordinate competitors, the risk of interaction may motivate spatial and/or temporal segregation of a contested resource in an attempt to avoid direct confrontation (e.g., Mills and Gorman 1997, Valeix et al. 2007) or, in extreme instances, intraguild predation (Palomares and Caro 1999). The latter has been well documented among canids (e.g., Johnson et al. 1996), and illustrates the risk of sharing space with fierce competitors. In order to coexist, subordinate competitors must develop behaviors to mitigate the risk of interspecific strife.

Avoidance of a dominant competitor is one means by which a subordinate competitor can reduce the effects of interspecific strife. Generally, avoidance behavior is manifest through spatial or temporal partitioning of the shared niche (Carothers and Jaksic 1984, Durant 2000). Under this

Received: 8 October 2010; Accepted: 6 March 2011;

Published: 3 August 2011

${ }^{1}$ E-mail: todd.c.atwood@aphis.usda.gov construct, a subordinate competitor may display adaptive resource selection by altering spatial (Atwood and Gese 2008) or temporal (Kotler et al. 1993, Atwood and Gese 2010) patterns of resource use based on the presence or absence of a dominant competitor. The success of such behavior is influenced, to a large extent, by heterogeneity in the distribution and quality of resource patches (Palmer 2003). For example, Mills and Gorman (1997) concluded that African wild dogs (Lycaon pictus) minimized the time they spent in prey-rich areas to avoid interactions with lions (Panthera leo), the primary source of wild dog mortality. Similarly, Thompson and Gese (2007) found that swift foxes (Vulpes velox) were less abundant in structurally complex habitats where prey and coyotes (Canis latrans), the primary source of mortality for foxes, were most abundant. Clearly, partitioning a resource is an effective strategy for avoiding strife when that resource is spatially variable. However, when a resource is spatially fixed, it is likely that aggregation will lead to interference behavior (Vahl et al. 2005) including aggressive interactions that result in direct contact.

The development of water features, such as stock tanks and artificial catchments, has become an integral part of livestock and wildlife management in the arid western United States where surface water often is absent or only seasonally available (e.g., Hervert and Krausman 1986, Holechek 1992). However, despite the obvious benefits, water features also have the potential to become foci of interspecific strife, and as competition for access intensifies so does the probability of contact between contestants (Thrash et al. 1995). In that way, resource-mediated contact may contribute to the 
maintenance of infectious disease (Barlow 1996). The most important diseases of carnivores (e.g., rabies, canine distemper, canine parvovirus) are caused by generalist pathogens capable of infecting multiple species and with a high potential for cross-species transmission (Nel et al. 1997, Kauhala and Holmala 2006, Roemer et al. 2009). Communal use of scarce resources, and the attendant direct and indirect contact that is likely to occur when attempting to exploit or defend those resources, may exacerbate the potential for cross-species pathogen transmission. Accordingly, examining the behavioral mechanisms underlying interspecific interaction at water features will provide a broader understanding of the connection between resource partitioning and the management of infectious agents in carnivore communities.

Coyotes, bobcats (Felis rufus), and gray foxes (Urocyon cinereoargenteus) are sympatric over much of their geographic range (Whitaker and Hamilton 1998), prey mainly on small mammals (Leopold and Krausman 1986, Neale and Sacks 2001a), are habitat generalists (Riley 2006, Neale and Sacks 2001b), and share susceptibility to many of the same pathogens (Riley et al. 2004). As a result, there is great potential for resource-mediated interaction (Fedriani et al. 2000) and cross-species pathogen transmission. We investigated resource partitioning by the 3 species in the Chihuahuan Desert of west Texas, by observing behavior at water features. We characterized and evaluated factors influencing activity patterns at water features, and investigated the influence of behavioral, habitat, and environmental covariates on relative activity at waters.

\section{STUDY AREA}

The study site was a privately owned $202 \mathrm{~km}^{2}$ cattle ranch in Pecos County, TX, on the northern edge of the Chihuahuan Desert. The area was characterized by scattered rugged hills and mesas crowned by boulders and rock piles. Elevation varied from 1,100-1,550 m. Slopes of hills and mesas were steep, and the tops of mesas typically supported little vegetation. Gullies were prevalent along the slopes of hills and mesas, and washes dissected the intervening valleys. Creosote bush (Larrea tridentata), Opuntia spp., and Agave spp. dominated lower slopes of hills, and western honey mesquite (Prosopis glandulosa) and greasewood (Sarcobatus vermiculatus) dominated valleys. Climate of the study area was arid, with precipitation $(28 \mathrm{~cm}$ annually) occurring mainly during the summer (Jul-Aug) monsoon season. Mean monthly temperatures ranged from a low of $5^{\circ} \mathrm{C}$ in December to a high of $28^{\circ} \mathrm{C}$ in July.

There was no free-flowing water present on the study site, although ephemeral pools existed during the monsoon season. Water was maintained in 35 stock tanks and 11 earthen impoundments via wells and a pumping and transport system. Stock tanks were either concrete or metal troughs, and were $3.6-\mathrm{m}$ long, $1-\mathrm{m}$ wide, and $0.8-\mathrm{m}$ deep. Impoundments ranged in area from 0.02 to 0.04 ha. Approximately 150 cattle were seasonally rotated around the ranch.

\section{METHODS}

We monitored 31 randomly selected water features (i.e., 25 tanks and 6 impoundments) using passive infrared-triggered cameras (Reconyx $^{\mathrm{TM}}$, Lacrosse, WI) from July 2009 through June 2010. We mounted cameras $45 \mathrm{~cm}$ above ground on rebar posts and positioned them to maximize the field of view (FOV). At tanks, we positioned cameras so that approximately $33 \%$ of the field of view (where FOV $=25 \mathrm{~m}$ at $15 \mathrm{~m}$ from the camera) included the tank and the remaining FOV included the surrounding area. At impoundments, we positioned cameras so that $33 \%$ of the FOV included the most accessible area to water as determined by trails and tracks. We programmed all cameras to capture an image after being triggered by motion and to record image sequences at 1-s intervals until all motion ceased. We monitored water features for 30 days over each of the following 3 seasonal intervals: summer (1 Jun-30 Sep); fall-winter (1 Oct-31 Jan); and spring (1 Feb-31 May). We rotated 20 cameras between the 31 features at 15-day intervals so that, on average, 30 days separated the first and second 15-day monitoring interval for a given water feature. We recorded date and time on all images.

Following VerCauteren et al. (2007), we defined camera monitoring effort as the summed time that all cameras were functional and available to record visits to water features, and scaled counts of visits by monitoring effort so comparisons among sites and intervals would be consistent (i.e., per $500 \mathrm{hr}$ of camera monitoring time). For each visit, we recorded the species, time, and duration (s) of attendance. We considered image sequences separated by $30 \mathrm{~min}$ to be independent events (Michalski and Peres 2007). We collected daily rainfall data $(\mathrm{cm})$ from the National Oceanic and Atmospheric Administration (NOAA) weather station at the Fort Stockton-Pecos County Airport, and assigned the values to an observation based on the time of the visit. The Fort Stockton NOAA weather station was located $21 \mathrm{~km}$ from the study site and although desert weather patterns can vary at a relatively fine scale, most variation can be attributed to differences in elevation (Comrie and Broyles 2002). Because the study site and weather station were relatively close to each other, at similar elevations, and because there was modest elevational change $(450 \mathrm{~m})$ on the study site, we believe the data recorded at the station reflected weather at the study site.

We collected data on habitat and physiographic attributes from a $30-\mathrm{m}$ plot centered on the water feature to determine if those attributes influenced use of waters. A sampling site consisted of $230-\mathrm{m}$ transects, 1 running east to west and 1 running north to south. At each site, we measured percent hiding cover and percent canopy cover. We measured percent hiding cover by visually estimating the percentage of an illustrated silhouette of a gray fox obscured at $15 \mathrm{~m}$ from the plot center (i.e., the intersection of the 2 transects) for each cardinal direction, and calculated the site value as the mean of the 4 measurements taken. We estimated percent canopy coverage by counting the number of points under canopy at $2-\mathrm{m}$ intervals for both $30-\mathrm{m}$ transect lines. We 
entered geo-referenced water features into a Geographic Information System (GIS) and extracted data on land cover type from a 30-m resolution National Land Cover Data Set (NLCD) coverage. We then used the GIS and methodology developed by Sappington et al. (2007) to calculate a ruggedness index from a seamless $30-\mathrm{m}$ resolution digital elevation model $(\mathrm{DEM})$ at the scale of $90 \mathrm{~m} \times 90 \mathrm{~m}\left(3 \times 330-\mathrm{m}^{2}\right.$ grid cells) and centered on the water feature. The ruggedness index incorporates heterogeneity of both slope and aspect within the sample frame and ranges from 0 to 1 as ruggedness increases.

\section{Statistical Analyses}

We conducted a randomization test for each species to determine if visits to the 31 monitored water features differed from random expectations. We summed the number of independent visits to all waters for each species and treated those visits as trials. We used a random number formula in Excel $^{\mathrm{TM}}$ (Microsoft Corporation, Redmond, WA) to assign each trial a number between 1 and 31 (i.e., bins), and ran 10,000 replicates to generate a uniform distribution of the most likely random expectation of the number of waters visited. We then compared the observed value of independent visits to the most likely random expectation to evaluate the null hypothesis of random visitation.

We derived diel activity patterns of focal species at waters, expressed as the percent of diurnal activity (DA), by categorizing images as diurnal and nocturnal based on sunrise and sunset tables (Naval Meteorology and Oceanography Command 2011) for Fort Stockton, Texas, and referenced to each of the 3 seasonal intervals. We estimated speciesspecific indices of relative activity (RA) for each camera station as the number of images of a species divided by the number of operational camera nights. We used generalized linear mixed models (GLMM) to characterize patterns of DA and RA at waters relative to time (i.e., seasonal interval), species, and dominant cover type. The GLMM approach enables the fitting of random terms and therefore accounts for repeated sampling across error terms. We sampled the same randomly selected water features repeatedly and thus included camera station as a random factor. We arcsin square root transformed both DA and RA to induce homoscedasticity, and tested all 2-way interactions of fixed factors and made a posteriori pairwise comparisons using least squares means tests (Zar 1999).

We used a GLMM to first characterize RA relative to seasonal interval, species (including livestock), and dominant cover type. Next, we developed linear models for each species using the species RA as the response variable, and habitat characteristics, carnivore and livestock activity, and water availability (i.e., days since last rainfall and nearest-neighbor distance to water) as predictor variables. For each species, we compared 5 candidate models: 1) habitat characteristics (i.e., percent hiding and canopy cover, nearest-neighbor distance to water, and ruggedness); 2) carnivore and livestock activity; 3) carnivore activity and ruggedness; 4) water availability; and 5) a global model comprised of variables from all the preceding models. The variable reflecting the nearest-neigh- bor distance to water (NNDIST) also served to assess potential spatial autocorrelation in the use of waters. We used Akaike Information Criteria with a small sample size correction factor $\left(\mathrm{AIC}_{c}\right)$ to select the most parsimonious model; models within $2 \mathrm{AIC}_{c}$ units of the minimum $\mathrm{AIC}_{c}$ model were considered competitive models with some support from the data (Burnham and Anderson 2002). We used Akaike weights $\left(w_{i}\right)$ to rank models based on relative support from the data. Finally, we estimated direct encounters for species pairs (i.e., coyote-cattle, coyote-bobcat, coyote-gray fox, gray fox-cattle, bobcat-cattle, and bobcat-gray fox) as a visit to a water feature during the same 5-min interval. Although assessing encounters within a 5 -min interval may overestimate direct encounters, we believe that it allows us to account for avoidance behaviors a subordinate competitor may display (e.g., waiting nearby to make the final approach) when in close proximity to a water feature being used by a competitor.

For all models, we checked continuous variables for conformity to linearity by residual analyses (Neter et al. 1996) and for collinearity using correlational analysis (we eliminated any one of a pair of variables with Pearson $r$ indicating more than 30\% correlation). For GLMM analyses, we used first-order autocorrelation as a covariance structure, the restricted maximum likelihood (REML) method for model estimation, and Satterthwaite's $F$ test to gauge effects (Littell et al. 2006). We also tested all 2-way interactions and made pairwise comparisons using least squares means tests. For linear models, we used maximum likelihood (ML) for model estimation. We accepted statistical significance for all analyses at $\alpha=0.05$.

\section{RESULTS}

Our camera monitoring effort was consistent among camera sites and interval, and ranged from 1,512 to $2,106 \mathrm{hr}$ per camera for a total of 36,240 camera hours for the study duration. Cameras recorded 916 visits by cattle, 132 by coyotes, 51 by bobcats, and 49 by gray foxes. Cattle spent the greatest amount of time (in seconds) at waters $(\bar{x}=1,098, \mathrm{SE}=237)$, followed by bobcats $(\bar{x}=88.21$, $\mathrm{SE}=19.85)$, coyotes $(\bar{x}=37.69, \mathrm{SE}=5.64)$, and gray foxes $(\bar{x}=23.60, \mathrm{SE}=6.21$; Table 1$)$. We observed coyotes at all 31 camera stations, which was the most likely outcome based on the randomization test ( $\mathrm{pr}[31]$, i.e., the probability of observing coyotes at 31 camera stations $=0.66)$. We observed bobcats at 26 stations $(\mathrm{pr}[26]=0.21)$, compared to the most likely random expectation of $25(\mathrm{pr}[23]=0.23)$.

Table 1. Relative activity and the percent of time spent at developed water features for cattle, bobcats, coyotes, and gray foxes from 2009 to 2010 in Pecos County, Texas, USA.

\begin{tabular}{lccc}
\hline Species & $\begin{array}{c}\text { Number of } \\
\text { observed sites }\end{array}$ & $\begin{array}{c}\text { Mean relative } \\
\text { activity (SE) }\end{array}$ & $\begin{array}{c}\text { Overall } \\
\text { \% time }\end{array}$ \\
\hline Cattle & 31 & $21.71(9.72)$ & 47 \\
Bobcat & 26 & $2.65(1.02)$ & 25 \\
Coyote & 31 & $2.24(0.98)$ & 20 \\
Gray fox & 21 & $0.38(0.21)$ & 8 \\
\hline
\end{tabular}


Gray foxes, on the other hand, appeared restricted in their use of waters; we observed them at 21 stations $(\operatorname{pr}[21]=0.02)$ compared to the most likely random expectation of $25(\mathrm{pr}[25]=0.23)$. We detected other species at water features including javelina (Tayassu tajacu), raccoons (Procyon lotor), striped skunks (Mephitis mephitis), badgers (Taxidea taxus), feral hogs (Sus spp.), porcupines (Erethizon dorsatum), white-tailed deer (Odocoileus virginianus), mule deer (Odocoileus hemionus), black-tailed jackrabbits (Lepus californicus), banner-tailed kangaroo rats (Dipodomys spectabilis), and turkey vultures (Cathartes aura).

\section{Activity Patterns}

The proportion of diurnal activity (DA) at water features differed among species $\left(F_{2,72.5}=3.68, P=0.040\right)$ but not by monitoring interval $\left(F_{2,72.2}=0.02, P=0.910\right)$ or cover type $\left(F_{3,72.9}=1.35, P=0.265\right)$. Least squares means tests indicated that the proportion of diurnal activity at water features was greatest for coyotes $(\bar{x}=0.59, \mathrm{SE}=0.09)$, but bobcats $(\bar{x}=0.42, \mathrm{SE}=0.11)$ also regularly visited waters during that interval. Conversely, gray foxes $(\bar{x}=0.002, \mathrm{SE}=0.08)$ rarely made diurnal visits to water features (Fig. 1). Similarly, relative activity (RA) differed among species $\left(F_{4,92.3}=10.60, P<0.001\right.$; Table 1$)$, but not by cover type $\left(F_{2,92.3}=0.36, P=0.702\right)$ or monitoring interval $\left(F_{2,92.2}=0.10, P=0.908\right)$. Interaction terms were not significant in either analysis. Because activity patterns were consistent across monitoring intervals, we pooled data across seasons for each camera site for subsequent analyses.

Linear models indicated that factors influencing RA at waters differed by species (Table 2). For coyotes and bobcats, the water availability model, comprised of variables representing days since last rainfall and nearest-neighbor distance to water, received the greatest support. For both species, days since rainfall explained the majority of the variation (coyote: partial $r^{2}=0.62$; bobcat: partial $r^{2}=0.58$ ) in the data. Based on water availability models, a unit (i.e., day) increase in days since last rainfall will result in $7 \%$ and $4 \%$ increases in RA for coyotes and bobcats, respectively. Finally, for gray foxes, the model with coyote and bobcat activity indices and topographical complexity received the greatest support with a weight of 0.98 (Table 2). Parameter estimates $(\beta)$ for relative activity for foxes decreased with increasing coyote $(\beta=-1.13)$ and bobcat $(\beta=-0.87)$ activity. For the top gray fox model, ruggedness $(\beta=1.51)$ explained a majority of variation (partial $r^{2}=0.65$ ) in the data, and was positively correlated with RA.

We observed 57 instances in which 2 or more species visited a camera station on the same day during the same 5-min interval. The majority (89\%) of those instances occurred during the nocturnal interval and $60 \%$ of all instances involved cattle (coyote-cattle: $n=25$; bobcat-cattle: $n=9$ ). Among carnivores, encounters were greatest for coyote-gray fox $(n=12)$, followed by coyote-bobcat $(n=7)$, and bobcat-gray fox $(n=4)$. No direct agonistic interactions between carnivore species or with cattle were captured in camera images.

\section{DISCUSSION}

Our work provides insight on how risk of interaction induces behavioral adjustments that facilitate the exploitation of a shared and limited resource by desert carnivores. We found evidence that carnivores temporally partitioned use of water features with coyotes and bobcats making substantially more diurnal visits to waters than gray foxes, which were relegated to mostly nocturnal visits. The behaviors mediating RA at water features differed among species, with RA of both coyotes and bobcats directly correlated with days since last rainfall. By contrast, RA for gray foxes was directly correlated with topographical complexity and inversely correlated with activity indices of the larger carnivores. The latter finding suggests that gray foxes also partition use of water features spatially to minimize the risk of interspecific strife. Finally, encounters at water features were generally higher for carnivore-cattle pairings than for carnivore-carnivore pairings. In all, these findings indicate that mechanisms influencing use of water features are nuanced; use by gray foxes primarily is modulated by mitigating interaction with competitors,

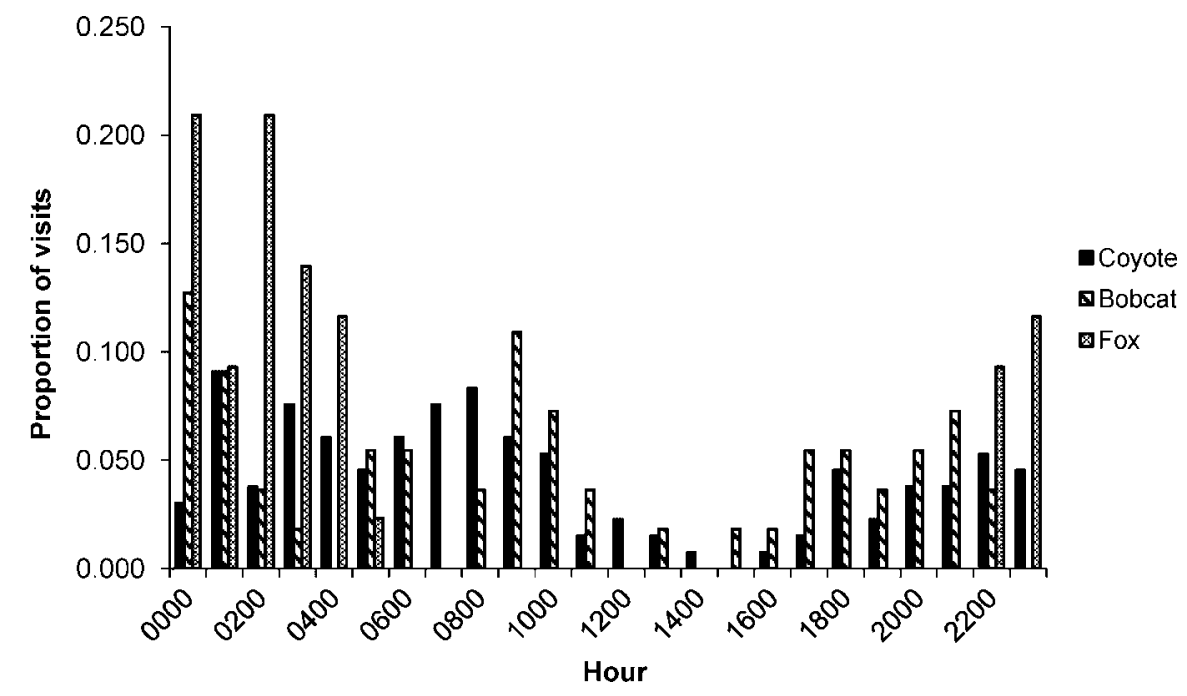

Figure 1. Activity patterns of coyotes, bobcats, and gray foxes visiting developed waters from 2009 to 2010 in Pecos County, Texas, USA. 
Table 2. Model results (number of variables [ $k]$, Akaike Information Criteria measure of each model relative to the best model [ $\Delta$ AIC $\left._{c}\right]$, and strength of evidence [i.e., Akaike weights, $w_{i}$ ] ) for factors influencing residency time of coyotes, bobcats, and gray foxes visiting developed water features from 2009 to 2010 in Pecos County, Texas, USA.

\begin{tabular}{|c|c|c|c|c|c|}
\hline Species & Model & $\begin{array}{c}\text { Sum of } \\
\text { squared error }\end{array}$ & $K$ & $\Delta \mathrm{AIC}_{c}$ & $w_{i}$ \\
\hline \multirow[t]{5}{*}{ Coyote } & Nearest neighbor distance to water + days since rainfall & 1.28 & 2 & 0 & 0.971 \\
\hline & Cattle activity + bobcat activity + fox activity & 2.38 & 3 & 7.13 & 0.028 \\
\hline & Bobcat activity + fox activity + ruggedness & 6.16 & 3 & 13.11 & $<0.001$ \\
\hline & Global & 2.43 & 8 & 24.36 & $<0.001$ \\
\hline & $\%$ hiding cover $+\%$ canopy cover + nearest neighbor distance to water + ruggedness & 5.31 & 4 & 27.61 & $<0.001$ \\
\hline \multirow[t]{5}{*}{ Bobcat } & Nearest neighbor distance to water + days since rainfall & 1.76 & 2 & 0 & 0.905 \\
\hline & Cattle activity + coyote activity + fox activity & 1.46 & 3 & 4.61 & 0.091 \\
\hline & Coyote activity + fox activity + ruggedness & 2.68 & 3 & 11.33 & 0.003 \\
\hline & $\%$ hiding cover $+\%$ canopy cover + nearest neighbor distance to water + ruggedness & 5.56 & 4 & 31.42 & $<0.001$ \\
\hline & Global & 6.79 & 8 & 47.77 & $<0.001$ \\
\hline \multirow[t]{5}{*}{ Gray fox } & Coyote activity + bobcat activity + ruggedness & 1.03 & 3 & 0 & 0.985 \\
\hline & Cattle activity + bobcat activity + coyote activity & 1.21 & 3 & 8.75 & 0.013 \\
\hline & $\%$ hiding cover $+\%$ canopy cover + nearest neighbor distance to water + ruggedness & 0.97 & 4 & 12.87 & 0.001 \\
\hline & Nearest neighbor distance to water + days since rainfall & 2.36 & 2 & 29.55 & $<0.001$ \\
\hline & Global & 2.84 & 8 & 41.28 & $<0.001$ \\
\hline
\end{tabular}

whereas use by coyotes and bobcats is modulated by environmental conditions.

Temporal partitioning of critical resources is commonly cited as a mechanism that facilitates sympatry (Ross 1986, Luiselli 2007). In most cases, the subordinate competitor is expected to adjust activity patterns to mitigate the risk of contact with the dominant competitor (Vieira and Port 2007, Hayward and Slotow 2009). When dominance hierarchies are clearly evident, the expectation of partitioning is often realized. However, when dominant-subordinate relationships are less obvious, either partitioning is not readily observable, or the effect size is small. Our finding of differential partitioning of the temporal niche by coyotes, bobcats, and gray foxes visiting water features provided a clear example of both. As expected, gray foxes behaved as a subordinate competitor to both coyotes and bobcats; time spent at water features was shortest for foxes and nearly all visits (i.e., $>97 \%$ ) occurred during the nocturnal interval. By contrast, $41 \%$ of coyote and $64 \%$ of bobcat visits occurred during the nocturnal interval, but time spent at water was greater for bobcats. As a result, there is no evidence of a dominant-subordinate relationship between coyotes and bobcats.

To understand why some species may be more likely to alter their temporal or spatial niches when visiting waters, it is important to understand how interference competition can induce behavioral adjustments that then exacerbate or ameliorate fitness costs (Abramsky et al. 2001, Valeix et al. 2007). Species visiting water features face a tradeoff between the benefit of timely maintenance of basic physiological needs (i.e., hydration, thermoregulation) and the cost of interspecific interaction. In carnivores, the mismanagement of this tradeoff can lead to dire consequences. For example, many studies of interspecific interactions between carnivores document instances of intra-guild predation (also see reviews by Palomares and Caro 1999 and Donadio and Buskirk 2006) that arise from exploitation of shared resources. Nevertheless, many of those same studies show that minor behavioral adjustments relative to prey selection and space use can be enough to facilitate detente (e.g., Kitchen et al.
1999, Fedriani et al. 2000, Thompson and Gese 2007). Of course, when the shared resource is prey or space, options typically exist for the subordinate competitor to expand their niche breadth and minimize overlap. However, when the shared resource is water, and is spatially fixed, there are considerably less opportunities to adjust exploitation behaviors to minimize risk of conflict. As a result, a subordinate competitor, such as the gray fox, must adapt their behavior to fluctuating risk in order to reach a precarious balance of meeting a basic physiological need while minimizing the likelihood of intra-guild predation.

Evidence suggests that gray foxes were adept at assessing risk of interspecific contact and adjusting their behavior to minimize that risk. Of the 31 water features monitored, we observed coyotes at all and bobcats at 26 . On the other hand, we detected gray foxes at 21 waters. Accordingly, foxes had little choice but to visit waters that were likely to be visited by coyotes and bobcats, and thus obligate spatial avoidance was not feasible. Rather, gray foxes implemented a form of hierarchical risk management by concentrating activity patterns at waters during nocturnal hours, minimizing residency time at waters based on coyote and bobcat activity indices, and maximizing time at waters that were located adjacent to rugged escape terrain. It was unclear whether behavioral adjustments by foxes was successful in minimizing the likelihood of contact with coyotes and bobcats, but it was clear that foxes were more likely to encounter carnivores than cattle. Although seemingly incongruous, the failure of behavioral adjustments to fully ameliorate the likelihood of hostile interaction is not novel. Valeix et al. (2007) reported similar findings with elephants and other herbivores visiting waterholes in African savanna; species more likely to suffer from costly interference shifted their temporal niches but still maintained temporal overlap and high interaction probabilities with the dominant competitor. Our observations are strikingly similar, and illustrate the central difficulty of managing risk; as complexities accrue, mitigating actions must become more refined. Foxes partition use of waters along axes of time and space, but there is little room on either axis that is not being used by a competitor. 


\section{MANAGEMENT IMPLICATIONS}

In arid environments, water features will act as focal attractors for wildlife and domestic animals, and may become foci for intra-guild strife and wildlife-livestock conflict. Although the easiest solution to managing water-mediated strife and conflict would be to remove all developed water features, it simply is not a practical alternative for lands where the primary use is livestock production. Accordingly, strategies developed to reduce the potential for interaction must capitalize on divergent behaviors displayed by users. Our finding that use of water features by coyotes and bobcats was primarily driven by days since last rainfall, whereas use by gray foxes was influenced by risk of interspecific strife, is a critical distinction to note. Our results indicate that gray foxes are most likely to intensively exploit water features when they are located adjacent to rugged escape terrain. These findings could provide an opportunity to use the strategic placement and maintenance of water features to mitigate strife between a dominant generalist competitor (e.g., coyote) and an at-risk subordinate competitor (e.g., kit fox; Vulpes macrotis) or manage the potential for conflict with other wildlife and livestock. Where strife and conflict are concerns, we recommend the systematic dispersion of resource features, which have been shown to reduce the potential for intra- and interspecific interaction (Wright and Gompper 2005). This could best be accomplished by overlaying an evenly-spaced grid, scaled to the focal species spatial requirements, on the area of interest and deploying and maintaining additional water features in grid cells deemed to contain the most suitable focal species habitat. Of course, the actions we recommend are intensive and may require additional infrastructure development (i.e., placement of water features) by land owners and managers.

\section{ACKNOWLEDGMENTS}

We gratefully acknowledge the financial support provided by the United States Department of Agriculture (USDA), Animal and Plant Health Inspection Service (APHIS), Wildlife Services, National Rabies Management Program. The USDA/APHIS/Wildlife Services-Texas provided logistical support. D. Sheldon, K. St. Clair, B. Jackson, S. Hunt, and T. Bryan provided valuable assistance in the field. We thank M. Bodenchuk, S. Turman, G. Phillips, and E. Oertli for their advice and help with various aspects of this research. We thank B. Kluever, K. McKelvey, O. Rhodes, and 2 anonymous reviewers for comments that greatly improved the manuscript. Finally, we thank the Hammond family for providing access to the study site.

\section{LITERATURE CITED}

Abramsky, Z., M. L. Rosenzweig, and A. Subach. 2001. The cost of interspecific competition in two gerbil species. Journal of Animal Ecology 70:561-567.

Atwood, T. C., and E. M. Gese. 2008. Coyotes and recolonizing wolves: social rank mediates risk-conditional behavior at ungulate carcasses. Animal Behaviour 75:753-762.

Atwood, T. C., and E. M. Gese. 2010. The importance of resource selection and social behavior to partitioning of hostile space by sympatric canids. Journal of Mammalogy 91:490-499.
Barlow, N. D. 1996. The ecology of wildlife disease control: simple models revisited. Journal of Applied Ecology 33:303-314.

Burnham, K. P., and D. R. Anderson. 2002. Model selection and inference: a practical information-theoretic approach. Second edition. SpringerVerlag, New York, New York, USA.

Carothers, J. H., and F. M. Jaksic. 1984. Time as a niche difference: the role of interspecific competition. Oikos 42:403-406.

Chase, J. M., P. A. Abrams, J. P. Grover, S. Diehl, P. Chesson, R. D. Holt, S. A. Richards, R. M. Nisbet, and T. J. Case. 2002. The interaction between predation and competition: a review and synthesis. Ecology Letters 5:302-315.

Comrie, A. C., and B. Broyles. 2002. Variability and spatial modeling of fine-scale precipitation data for the Sonoran Desert of south-west Arizona. Journal of Arid Environments 50:573-592.

Connell, J. H. 1983. On the prevalence and relative importance of interspecific competition: evidence from field experiments. American Naturalist 122:661-696.

Crooks, K. R., and D. Van Vuren. 1995. Resource utilization by two insular mammalian carnivores, the island fox and island spotted skunk. Oecologia 104:301-307.

Davies, T. J., S. Meiri, T. G. Barraclough, and J. L. Gittleman. 2007. Species co-existence and character divergence across carnivores. Ecology Letters 10:146-152.

Donadio, E., and S. W. Buskirk. 2006. Diet, morphology, and interspecific killing in Carnivora. American Naturalist 167:524-536.

Durant, S. M. 2000. Living with the enemy: avoidance of hyenas and lions by cheetahs in the Serengeti. Behavioral Ecology 11:624-632.

Fedriani, J. M., T. K. Fuller, R. M. Sauvajot, and E. C. York. 2000. Competition and intraguild predation among three sympatric carnivores. Oecologia 125:258-270.

Hayward, M. W., and R. Slotow. 2009. Temporal partitioning of activity in large African carnivores: tests of multiple hypotheses. South African Journal of Wildlife Research 39:109-125.

Holechek, J. L. 1992. Financial benefits of range management practices in the Chihuahuan Desert. Rangelands 14:279-284.

Hervert, J. J., and P. R. Krausman. 1986. Desert mule deer use of water developments in Arizona. Journal of Wildlife Management 50:670676.

Johnson, W.E., T.K. Fuller, and W.L. Franklin. 1996. Sympatry in canids: a review and assessment. Pages 198-218 in J. L. Gittleman, editor. Carnivore behavior, ecology, and evolution. Cornell University Press, Ithaca, New York, USA.

Kauhala, K., and K. Holmala. 2006. Contact rate and risk of rabies spread between medium-sized carnivores in southeast Finland. Annales Zoologica Fennici 43:348-357.

Kitchen, A. M., E. M. Gese, and E. R. Schauster. 1999. Resource partitioning between coyotes and swift foxes: space, time, and diet. Canadian Journal of Zoology 77:1645-1656.

Kotler, B. P., J. S. Brown, and A. Subach. 1993. Mechanisms of species coexistence of optimal foragers: temporal partitioning by two species of sand dune gerbils. Oikos 67:548-556.

Leopold, B. D., and P. R. Krausman. 1986. Diets of 3 predators in Big Bend National Park, Texas. Journal of Wildlife Management 50:290295.

Littell, R. C., G. A. Milliken, W. W. Stroup, R. D. Wolfinger, and O. E. Schabenberger. 2006. SAS for mixed models. Second edition. SAS Institute, Inc., Cary, North Carolina, USA.

Luiselli, L. 2007. Resource partitioning and interspecific competition in snakes: the search for general geographic and guild patterns. Oikos 114:193-211.

Michalski, F., and C. A. Peres. 2007. Disturbance-mediated mammal persistence and abundance-area relationships in Amazonian forest fragments. Conservation Biology 21:1626-1640.

Mills, M. G. L., and M. L. Gorman. 1997. Factors affecting the density and distribution of wild dogs in the Kruger National Park. Conservation Biology 11:1397-1406.

Naval Meteorology and Oceanography Command. 2011. Sun or moon rise/ set table for one year. <http://aa.usno.navy.mil/data/docs/RS_OneYear. php $>$. Accessed 11 Jan 2011.

Nel, L., J. Jacobs, J. Jaftha, and C. Meredith. 1997. Natural spillover of a distinctly Canidae-associated biotype of rabies virus in an expanded wildlife host range in southern Africa. Virus Genes 15:79-82. 
Neale, J. C. C., and B. N. Sacks. 2001a. Food habits and space use of gray foxes in relation to sympatric coyotes and bobcats. Canadian Journal of Zoology 79:1794-1800.

Neale, J. C. C., and B. N. Sacks. 2001b. Resource utilization and interspecific relations of sympatric bobcats and coyotes. Oikos 94:236-249.

Neter, J., M. H. Kutner, C. J. Nachtsheim, and W. Wasserman. 1996. Applied linear statistical models. Fourth edition. McGraw-Hill, Boston, Massachusetts, USA.

Palmer, T. M. 2003. Spatial habitat heterogeneity influences competition and coexistence in an African acacia ant guild. Ecology 84:2843-2855.

Palomares, F., and T. M. Caro. 1999. Interspecific killing among mammalian carnivores. American Naturalist 153:492-508.

Polis, G. A., C. A. Myers, and R. D. Holt. 1989. The ecology and evolution of intraguild predation: potential competitors that eat each other. Annual Review of Ecology and Systematics 20:297-330.

Riley, S. P. D. 2006. Spatial ecology of bobcats and gray foxes in urban and rural zones of a national park. Journal of Wildlife Management 70:14251435.

Riley, S. P. D., J. Foley, and B. Chomel. 2004. Exposure to feline and canine pathogens in bobcats and gray foxes in urban and rural zones of a national park in California. Journal of Wildlife Diseases 40:11-22.

Roemer, G. W., M. E. Gompper, and B. Van Valkenburgh. 2009. The ecological role of the mammalian mesocarnivore. Bioscience 59:166173.

Ross, S. T. 1986. Resource partitioning in fish assemblages: a review of field studies. Copeia 2:352-388.

Sappington, J. M., K. M. Longshore, and D. B. Thompson. 2007. Quantifying landscape ruggedness for animal habitat analysis: a case study using bighorn sheep in the Mojave Desert. Journal of Wildlife Management 71:1419-1426.
Schoener, T. W. 1983. Field experiments on interspecific competition. American Naturalist 122:240-285.

Thompson, C. M., and E. M. Gese. 2007. Food webs and intraguild predation: community interactions of a native mesocarnivore. Ecology 88:334-346.

Thrash, I., G. K. Theron, and J. P. Bothma. 1995. Dry season herbivore densities around drinking troughs in the Kruger National Park. Journal of Arid Environments 29:213-219.

Vahl, W. K., J. van der Meer, F. J. Weissing, D. van Dullemen, and T. Piersma. 2005. The mechanisms of interference competition: two experiments on foraging waders. Behavioral Ecology 16:845-855.

Valeix, M., S. Chamaille-Jammes, and H. Fritz. 2007. Interference competition and temporal niche shifts: elephants and herbivore communities at waterholes. Oecologia 153:739-748.

VerCauteren, K. C., M. J. Lavelle, N. W. Seward, J. W. Fischer, and G. E. Phillips. 2007. Fence-line contact between wild and farmed white-tailed deer in Michigan: potential for disease transmission. Journal of Wildlife Management 71:1603-1606.

Vieira, E. M., and D. Port. 2007. Niche overlap and resource partitioning between two sympatric fox species in southern Brazil. Journal of Zoology 272:57-63.

Whitaker, J. O., and W. J. Hamilton. 1998. Mammals of the Eastern United States. Comstock, Ithaca, New York, USA.

Wright, A. N., and M. E. Gompper. 2005. Altered parasite assemblages in raccoons in response to manipulated resource availability. Oecologia 144:148-156.

Zar, J. H. 1999. Biostatistical analyses. Fourth edition. Prentice Hall, Upper Saddle River, New Jersey, USA.

Associate Editor: Kevin McKelvey. 